\title{
The First 25 Years of Computers in Education in Poland: 1965 - 1990
}

\author{
Maciej M. Sysło \\ Institute of Computer Science, University of Wrocław, Poland \\ syslo@ii.uni.wroc.pl \\ http://mmsyslo.pl/
}

\begin{abstract}
The first regular informatics lessons in schools were organised in Poland in the second half of the 1960s. Some of the lessons in Wrocław were devoted to programming a mainframe computer located at the university, and school students in Warsaw had a chance to learn theoretical models of computers and foundations of computations.

In the mid-1970s, the government of Poland recognised the importance of computers in the state economy and also in preparing the society for new challenges in the job market and social life. Several national programs and projects were initiated and funded by public money which brought to schools the key components of computer education technology, such as: microcomputers (Elwro 800 Junior), curriculum and syllabuses, educational software, textbooks and materials for teachers, journals. In this paper we shortly characterise all these components and describe their role in informatics education in Polish schools.

The 'investments' in the area of new educational technology, hard and soft, technical and intellectual, made in the 1960-1980s to the education system in Poland, have paid off in the next years and until today, when technology, such as the Internet and mobile tools, are rapidly changing our lives and education.
\end{abstract}

Keywords: Education, Poland, schools, types of computer, teacher training.

\section{$1 \quad$ Introduction and Preliminaries}

The development of educational technology based on computers closely follows the development of computer technology. First regular lessons on informatics were organised in Poland in the second half of the 1960s - see Section 2. At that time there were only a few computers (mainframes) in Poland and none of them was installed in a school. Pioneers of informatics education in Wrocław decided to allow school students to spend some time programming a real computer in the university computing centre, whereas in Warsaw the first informatics lessons in a school were on theoretical models of computers and computations. In both cases leading mathematicians and computer scientists played the main role in introducing informatics ideas to schools and running the first lessons in classrooms. 
Shortly after the first informatics lessons in schools it became obvious that a proper preparation of school teachers would be crucial for the success of computerisation of learning and teaching. The first in-service course for future teachers of informatics was organised in the mid-1970s in Warsaw.

In the mid-1970s, a first sign about the importance of the electronic revolution to the most crucial branches of economy, industry, education, and social life came from the government (as a resolution). In the highly centralised political system in Poland of the 1960-1980s, such resolutions opened many doors and were followed by specific programs and projects, and, the most important - by the state funding. New resolutions, government programs and projects had been announced in the 1980s.

The official history of computers in Polish schools started in 1985, in the beginning of the personal computer era, with the first official informatics curriculum proposed by the Polish Information Processing Society (PTI) and approved by The Ministry of National Education (MEN).

In the second half of the 1980s one could observe very intensive activities of various state, public and private institutions which resulted in many ideas and products delivered to 'the education market', in particular to students, teachers, and to schools. Among them were: curricula and syllabuses, textbooks, educational software, journals and magazines, conferences.

We are proud in Poland that informatics, introduced to the curriculum in 1985, has reminded in the core curriculum for all these years till today.

The chapter is organised as follows. In this Section we shortly present the education system in Poland in the last 50 years and explain some terms used here. In Section 2 we characterise the first informatics classes which were organised in the second half of the 1960s in schools in two cities in Poland, and Section 3 is devoted to the first in-service training of informatics teachers which was ran in the mid-1970s in Warsaw. Government resolutions, programs and projects are presented in Section 4 and Section 5 is on the Polish school microcomputer Elwro 800 Junior and its software. In Section 6 we describe the situation in schools in the second half of the 1980s with regard to the main components of informatics education: curriculum, textbook, educational software, journals, conference for teachers, partners. At the end we list some of the sources, in majority in Polish.

\subsection{The Education System in Poland in the Second Half of the $20^{\text {th }}$ Century}

In the period from $1948 / 1949$ to $1998 / 1999$ the formal school system at primary and secondary levels in Poland consisted of two stages; from 1948/1949 to 1965/1966:

- $\quad$ primary school - 1-7 grades (age 7 to 14 );

- high school - 8-11 grades (to 12 in certain vocational schools) - (age 14 to 18); and from $1966 / 1967$ to $1998 / 1999$, to better prepare young students for their further education and personal vocational career in the future, primary school was extended by one year:

- $\quad$ primary school - 1-8 grades (age 7 to 15 );

- high school - 9-12 grades (to 13 in certain vocational schools) - (age 15 to 19);

Since 1999/2000, the formal school system consists of three stages: 
- $\quad$ primary school - 1-6 grades (age 7 to 13 );

- middle school (in Polish: gimnazjum) - 7-9 grades (age 13 to 16);

- high school - 10-12 grades (to 13 in certain vocational schools) - (age 16 to 19).

Formal education started in Poland at the age of 7 and now it moves down to 6 (in 2014 all children will go to school when they are 6). The school grades in Poland in the period 1965-1990 were in the range [2-5], with 2 as fail.

\section{$1.2 \quad$ Terminology}

In this paper we use today's terminology: computer, informatics, informatics education, Ministry of National Education (MEN). In Poland, a computer was called 'a mathematical machine' in the 1960s, although the term 'computer' was used for the first time in 1963, and the term 'informatics' for computer science was introduced in the late 1960s. The ministry responsible for education in K-12 has changed its name several times.

In the education system in Poland, informatics education consists of two types of classes or/and activities:

- separate computer (in elementary school) and informatics (in middle and in high) classes;

- across-curriculum integration of computers, information and communication technology, and Internet with learning and teaching of all subjects.

In this article, in which we describe early activities in Poland in the area of computers in education, our focus is mainly on learning and teaching about computers. In the beginning, with a few exceptions, informatics (understood as computer science) dominated as a subject, since there was no subject-oriented software and first computers coming to schools were used to build computer labs then used mainly by teachers of informatics. This fits into the model for technology development in education [UNESCO, 2002], which consists of four stages. In the first stage - Emerging - schools begin to get equipment and software (technology in general) and teachers are learning new educational technology and exploring the possibility and consequences of adding technology to the curriculum. Integration of technology with other subjects is the goal of the next stages - Applying and Infusing which follow the first stage.

\section{First Informatics Classes in Schools}

In this Section we describe two initiatives which in the 1960-1970s appeared in two academic centres in Poland, in Wrocław and in Warsaw. They were different in nature, since they were born in different circumstances. At the University of Wrocław in 1962, the Numerical Methods Division (KMN) was established within the Mathematical Institute and the mainframe computer (Elliott 803, made in the UK) was installed as the first commercially made computer in universities in Poland. In 1964/1965, academic teachers from KMN offered some school students informatics classes with a possibility to write programs and to run them on a real computer. 
On the other hand in Warsaw, although there were several institutions which hosted mainframe computers (also University of Warsaw), the informatics lessons, which started in 1970, were run in two university mathematics classes and were devoted mainly to some theoretical foundations of informatics. Other initiatives born in Warsaw in the 1970s were: informatics syllabus for schools and in-service courses for mathematics teachers on teaching informatics in high schools, both supervised by the Institute of Teacher Education (IKN) - see Section 3. According to Andrzej Walat, in the second half of the 1970s, informatics was taught in about 1000 high schools in Poland, mainly by teachers who were prepared during the IKN courses.

There were several other institutions and companies all over Poland which in the 1960-1970s offered lessons, courses and regular classes to students from primary and high schools. They were ran by the personnel of those institutions/companies graduated in informatics related fields and using their computer equipment.

It is worth mentioning that the first classes of informatics in schools in Poland were initiated by leading mathematicians and computer scientists of their time working in academic institutions in Wrocław and in Warsaw. Informatics lessons, addressed to students in mathematics classes extended their knowledge and skills by including computer (numerical) methods and programming of a real computer in Wrocław, and theoretical foundations of computers' design and calculations in various models of computations. Teachers and instructors in schools and also students involved in the first informatics classes in Poland admit today a great concern, engagement and activity of the initiators of those first classes - professors Stefan Paszkowski in Wrocław and Hanna Szmuszkowicz and Zdzisław Pawlak ${ }^{1}$ in Warsaw - their enthusiasm was shared by all participants in these activities, students and teachers, in schools and in academic institutions.

\subsection{Numerical Methods and Programming in Wrocław}

The first informatics class in Poland was established in the Adam Mickiewicz High School III (grade X) in Wrocław in the 1964/1965 school year ${ }^{2}$. It was partly initiated by The Science and Technology Council of the Regional Party Committee (PZPR $)^{3}$ and approved by MEN (the Ministry of Education). The decision was influenced by the University of Wrocław initiative (in 1962) to buy a commercial computer Elliott 803 , to open a numerical track (specialisation) and offer it to mathematics students. The school subject was called 'Programming and using a computer' and its syllabus was proposed by KMN, University of Wrocław (see [Witek, 1966], [Zuber, 1966]). Since those days a computer was mainly used for numerical calculations, students in this first informatics class learnt some basic numerical methods for solving mathematical problems and some programming languages for Elliott 803 (assembler, autocode Mark III, and Algol) and finally ran their programs on the real computer.

\footnotetext{
${ }^{1}$ See short bio of Zdzisław Pawlak: http: / / chc60. fgcu. edu/EN/HistoryDetail. aspx?c=12

${ }^{2}$ Another such class in Wrocław was open in the High School I in the next school year.

${ }^{3}$ PZPR - the Polish United Workers' Party.
} 
The students enrolled for informatics classes (also from other high schools in Wrocław) were supposed to have grade 4 or above in mathematics in the previous year. Out of 36 school hours a week, students in the informatics class had 8 hours of mathematics, 4 hours of informatics and 1 extra hour for elements of electronics (as a part of physics). The syllabus of mathematics (proposed by S. Paszkowski [Witek, 1966], [Zuber, 1966]) was extended and augmented by adding some sections and topics related to numerical methods and computer calculations such as: error analysis, mathematical tables and interpolations, polynomials, solving algebraic equations and systems of linear equations, numerical integration.

Informatics, taught by Roman Zuber, Jerzy Kucharczyk, Henryk Bogdanów and some other members of the University Computing Centre, covered: programming (first in autocode Mark III, then in assembler, and finally in Algol 60) binary representations, computer organisation, and computer implementations of numerical algorithms. For a particular problem to be solved or a topic to be discussed, time of teaching and learning was split into 4 parts: designing a solution as a computer program (50\% of the time assigned), making a program ready (punching) for running $(12,5 \%)$, running a program $(12,5 \%)$, discussions in groups $(25 \%)$. Parts 1 and 4 took place in the school classroom, and Parts 2 and 3 were held in the Computing Centre. Today, it is interesting to notice that during part 4, a teacher was helping and advising students how to cope with problems which may occur in the process of algorithm implementation and when verifying correctness of a solution, also in the case of home assignments. It reminds what today is called a flipped learning, a learning and teaching method in which a teacher spends most of his time on advising students on the problems they meet in their personal learning.

While solving a problem, students proceeded through all stages of solving a problem with a computer, what today is called algorithmic thinking (or computational thinking): describe a specification of a problem, choose an algorithm and data structure, implement an algorithm as a computer program, run a computer program, analyse outputs obtained and verify the correctness of your solution, discuss possible applications of your solution. In his evaluation of programming lessons, R. Zuber [Zuber, 1966] considered the stage of computer implementation of an algorithm as a specific communication dialog man-machine in which, contrary to a teacher, a machine is a formal and objective partner (tool), what Donald E. Knuth described precisely:

\section{It has often been said that a person does not really understand something until he teaches it to someone else. Actually a person does not really understand something until he can teach it to a computer.}

[Donald E. Knuth, AMM 81(1974)]

In the first years of informatics classes there were no textbooks for the school lessons. Teachers had to use hand-outs. In the next years, some texts were published on: Algol [Paszkowski, 1965], programming Elliott 803 [Łukaszewicz, 1966] and numerical methods and programming [Zuber, 1972].

The first class was attended by 19 students, and only 2 of them quit due to some health problems. In the beginning, there was a problem with different levels of 
students' competencies in mathematics brought from various schools they came, however after 2-3 months this problem disappeared. Close to $90 \%$ of students completed the first year of informatics lessons with the grade 4 or higher, [Witek, 1966], [Zuber, 1966].

Most of the students who graduated from informatics classes in high schools III and $I$ in Wrocław continued their study in informatics related disciplines and found jobs related to computers, some of them in University of Wrocław, where a few of them are still employed.

\subsection{Theoretical Foundations of Computer Science in Warszawa}

In contrast to the Wrocław initiative, in which the specialisation of S. Paszkowski group in $\mathrm{KMN}$ and the access to a computer decided that informatics lessons were devoted to numerical methods implemented on the real computer, a Warsaw initiative of introducing informatics to schools, undertaken in the beginning of the 1970s, was not tied up with computer programming. It was not a result of lack of computer access - computers were in operation in many places in Warsaw - it was the result of the idea of those who carried the initiative that teaching informatics to school students should focus mainly on the foundations of informatics to build a solid base for the future needs and interests in informatics related topics when students find jobs in different areas.

Informatics lessons in Warsaw were initiated in 1970 by mathematicians Hanna Szmuszkowicz, Stanisław Mazur, and Zdzisław Pawlak, in two university mathematics classes in the Klement Gottwald (today Stanisław Staszic) High School XIV (LO XIV). In the beginning, Andrzej Skowron, Andrzej Walat and Piotr Dembiński taught the theory of mathematical machines (Pawlak's machines, [Pawlak, Skowron, 1970], [Pawlak, 1971]) and the foundations of the finite automata theory. The focus was on understanding the meaning of algorithm and algorithmic problem solving using: a notion of the program for a von Neumann machine (in connection to universal Turing machine), algorithms coded in assembler, and algorithms represented by flow charts. In general, an algorithm was determined as a constructive method defining its transition function and the function calculated by the algorithm. In the next years, A. Walat taught some elements of programming - students wrote programs in Pascal in the classroom and then they could run their programs in one of the computing centres in Warsaw.

In the fall of 1970, H. Szmuszkowicz established in the Institute of Pedagogy a weekly seminar for teachers from Warsaw high schools interested in informatics and its teaching. The seminar was supervised by Z. Pawlak, who shaped its program and suggested topics and materials for discussion, and ran by A. Skowron and A. Walat. Topics of the first meetings of the seminar covered the theory of Pawlak's machines and analysis of the syllabus of informatics and educational materials used in High School XIV. Z. Pawlak, A. Skowron, and A. Walat wrote a textbook and classroom materials for students in LO XIV, [Pawlak, 1971], [Skowron, 1970, 1976], [Walat, 78].

In the beginning of the 1970s in IKN, a group of academic and school teachers started to work on a syllabus for informatics lessons in mathematics classes in high 
schools in Poland and on another syllabus for in-service training of mathematics teachers to prepare them for teaching in informatics classes. The first in-service course for 300 teachers, coming from different high schools in Poland, was organised in 1974 (see Section 3). A group of 20 teachers was selected who were asked to teach informatics for 2 hours a week in their schools according to the syllabus completed in IKN. Feedback from those teachers, from their schools, and from their students were used to modify the syllabus. The same group of teachers prepared materials for teaching informatics in schools and to run a course on didactics of informatics for participants of the IKN in-service course.

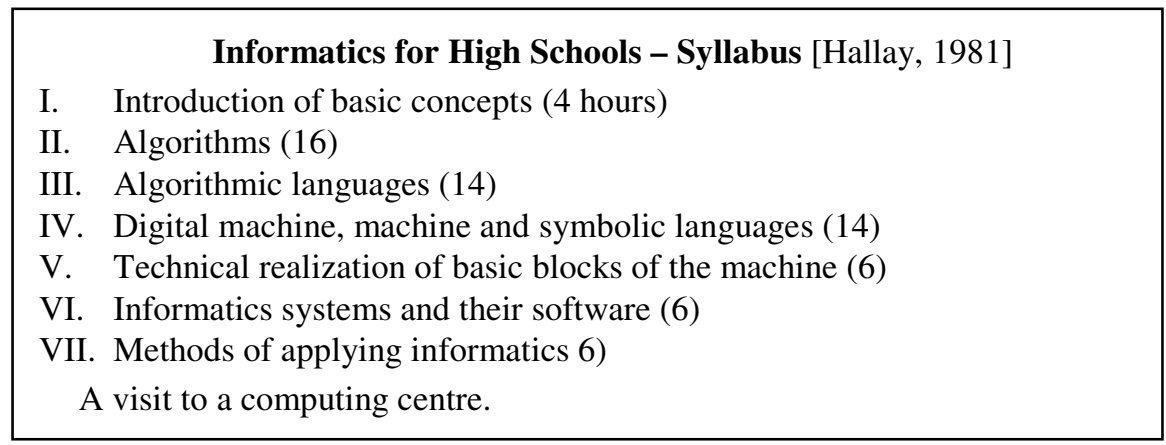

In contrast to the Wrocław syllabus for informatics, it was assumed in the IKN syllabus that informatics may be taught with no access to computers. It was only advised to visit a computing centre equipped with a computer.

Jerzy Hallay, one of the authors of the first Warsaw informatics syllabus and an instructor at the IKN in-service courses for teachers commented on the syllabus [Hallay, 1981]:

The ability to use a computer ... is not any more a competence of a small group of experts. We may assume that informatics systems will significantly influence everyday life of a whole society, as well as our personal life. ... additionally, there is no doubt that the way of thinking supported by informatics ... contributes to better organisation of a man in every domain of her/his activity. Knowledge and skills acquired when constructing algorithms perfectly form attitudes of honest and consequent behavior. In particular, the syllabus puts the main stress on elements of general education which develops critical and effective thinking. The syllabus does not impose teaching of effective programming, however it is assumed that students will understand the main ideas behind programming and know basic programming constructions from various programming languages. Moreover, no particular computer should be the object of instruction, however students should learn general ideas and laws of how computers work and their importance in the contemporary world. 
Note, that these words, written a long time before the microcomputer and mobile technology era, almost exactly describe what today is known as computational thinking - the mental competence, based on the power and limits of computers and computations, useful when solving problems in various domains with the help of computers, and augmenting traditional 3R literacies.

Syllabuses for informatics classes, informatics lessons in selected schools, and teacher training, initiated and conducted in the 1960-1970s in several regions in Poland, especially in Wrocław and in Warsaw, stimulated awareness of teachers in schools, decision makers in the area of education, and politicians and then activities and decisions, which in the mid-1980s, when computers became easily available for schools, universities, and private homes, formed a solid base for computerization of all schools and universities - see Section 4.

\section{$3 \quad$ First Initiatives in Teacher Preparation}

Teachers and their preparation are the most important factors when introducing any change to an education system, especially when introducing a new education technology. The first informatics classes described above were taught by academic teachers with the background mostly in mathematics, according to syllabuses written by teams which were also rooted at academic institutions. There are two types of preparations expected from teachers in the area of computers in education:

- to teach informatics as a separate subject;

- to incorporate and integrate computers, technology and informatics with other subjects.

It is also expected that informatics teachers can help teachers of other subjects in their schools to use computers and technology in various disciplines. Graduates from informatics-oriented faculties are not really interested in teaching in schools since they are convinced that all other informatics jobs are much better paid. On the other hand, new teachers of other subjects are prepared in a very traditional way with the main emphasis put on psychology and pedagogy and with only general ideas about the use of technology in teaching and learning and the impact technology can make on students learning and on teaching methods. Most of the teachers get their preparation to teach informatics or to use technology as a learning and teaching tool during in-service training.

As mentioned above, the first in-service course for 300 mathematics teachers to learn what and how to teach informatics in high schools, supervised by $\mathrm{H}$. Szmuszkowicz (in the beginning) and then by J. Hallay, was organised in the summer of 1974 by IKN. This course was preceded by a seminar on teaching informatics which ran for more than 2 years by IKN in cooperation with Universities in Warsaw and in Wrocław, and attended by academic and school teachers not only from these academic centres. In the first years, the course consisted of two parts, theoretical (held in Nowy Sącz, Pułtusk, Kalisz, Piotrków Trybunalski) - with no access to computers, and practical in computing centres equipped with mainframes (in Gdynia and Warsaw). 
In the beginning, the course for teachers was dominated by two topics (subjects): organisation of mathematical machines (a textbook was written by M. Stolarski) and foundations of informatics (a textbook was written by J. Hallay). Moreover, A. Walat published two collections of exercises on foundations of informatics [Walat, 1978], and A. Skowron wrote a text on foundations of the theory of mathematical machines [Skowron, 1974].

Teachers who attended in-service courses ran by the IKN, used in their schools the syllabus for informatics classes prepared also in IKN (see Section 2). The feedbacks from schools were then used to modify the informatics syllabus for schools and, after some years, were collected in the form of didactic materials for the next groups of teachers attending the in-service training courses.

The first in-service course for teachers of informatics was highly evaluated by MEN and all instructors received medals from the minister of education, Jerzy Kuberski.

It was estimated by A. Walat that by 1980 , more than 1,000 teachers attended inservice courses for teachers of informatics, and informatics was taught in more than 1,000 high schools in Poland, however most of the classes had no access to any computer.

The in-service course for teachers ran by IKN has changed its syllabus in the mid1980s when microcomputers (ZX Spectrum and compatibles) became popular in Poland and also arrived in schools, see [Wasiak, 2014]. A team arranged by PTI and supervised by S. Waligórskiego (University of Warsaw) published a new syllabus for informatics in high schools, approved by MEN to be used in schools, see Section 6.1. Another team, also supervised by S. Waligórski, prepared a Polish-language version of Logo for ZX Spectrum. S. Waligórski modified also the syllabus for the in-service teacher training course - the teachers were supposed to use computers during all lessons of the course - in the beginning it was ZX Spectrum, then Elwro 800 Junior, and finally IBM PC. Theoretical lessons (lectures) almost disappeared replaced by practical lessons with microcomputers. The subject on organisation of mathematical machines was gradually replaced by exercises with application software which was just in the beginning of its route to today's popularity. Programming started with Logo, and then continued with Pascal. In the second half of the 1980s, teachers attending the preparation course could use textbooks published for students in schools or for other users of microcomputers, which became popular also at homes.

In the 1980s, many universities and computer training centres started to offer teachers in-service courses on different aspects of microcomputers and their use in schools for separate informatics classes and for supporting learning and teaching other subjects.

Learning programming in general and programming in Pascal in particular were among the most popular courses offered for teachers as well as for students, in schools and also as off-school activities. Jan Madey from Warsaw University was a leading teacher in these courses; he also co-authored a textbook on Pascal ([Iglewski et al., 1979]) and wrote many educational materials on programming. 


\section{Government Documents, Decisions and Actions}

In the mid-1970s the government of Poland adopted the Resolution No. 175/75 'The Program of Electronisation of the National Economy to 1990'. The main goal of this program (called Program I hereafter) in the area of education was: to popularise and modernise the education system, and as a result, to upgrade the education of the society by implementing and using in instruction modern electronic tools, such as: TV, language labs, didactic machines, electronic calculators, computer terminals. It was the first sign that the government had recognised the importance of the electronic revolution to the most important branches of economy, industry, education, and social life.

In 1983 Program I was evaluated as not meeting the original goals and expectations. It was due to the increase of its public funding and, more important, due to rapid changes in computer technology after the world premiere of a personal computer IBM PC in 1981. In 1983, Program I was replaced by Program II established by the Resolution No. 77/83 'The Program of Electronization of the National Economy and the Directions of the Development of the Electronic Industry to 1990 '.

\subsection{Government Programs}

As a follow up of the Resolution 77/83, two programs addressed education were established by the government based on the proposals submitted by the committees of specialists in informatics and education:

1. Program III: 'Program for Public Education in the Area of Informatics and for Computer Techniques Applications in General and Vocational Schools in 1986-1990', Warsaw, March 1986.

2. Program IV: 'Program for Development of Computer Techniques Applications in Higher (University) Education in 1986-90', Warsaw, December 1985.

\subsubsection{Program III}

The main goal of Program III was: to make it possible for school and university students to learn informatics methods and tools to be able to use technical tools based on computer techniques as ordinary tools in their jobs and in daily life. Moreover, it was assumed that computers will be used as educational tools and this will lead to better and new achievements in education ... One of the goals of our education system is to create and develop in students informatics culture understood as ability of applying computers as modern job tools, used also in exploring various application areas ... Informatics content should not be designed only according to informatics and computer techniques standards but also taking into account general education goals, corresponding to levels of education and types of schools. Four areas of the Program activities were distinguished: 
- teacher preparation;

- hardware and software (application and educational);

- publications (journals and textbooks);

- research and development.

Program III was signed by the vice-ministers of education and of higher education, and also by a government member Aleksander Kwaśniewski, a future President of Poland, who was in charge of youth affairs in the government.

\subsubsection{Program IV}

Program IV was devoted to computerisation of higher education institutions (universities) in the area of education and research. It was assumed that informatics education of all students in higher education institutions is the most important way for the effective development of informatics and its applications in the national economy. Program IV consisted of two main components:

- education of future specialists in informatics, responsible for the development of informatics methods and tools, and also for training of other informatics specialist and educators;

- informatics education addressed to all students, to prepare them for using informatics methods and tools in their future jobs regardless of the area of interests.

\subsubsection{Ministry of National Education (MEN)}

In the mid-1980s, a special department was established in the Ministry of National Education which was (and still exists) to manage and monitor activities ran by government agencies and other institutions in the area of computerisation of schools. In the 1960-1980s the education system in Poland was highly centralised. In the 1980s the department was chaired by Zbigniew Rogowski with the help of Krzysztof Święcicki.

\subsection{Government Projects}

In the second half of the 1980s, several projects were established to accomplish the goals of Programs III and IV. Two of them, RRI.16 and RRI.14, were the most important with regard to their achievements for general informatics education.

\section{Project RRI.16}

The goal of Project RRI.16: 'Informatics for Schools - Development of Informatics Education in High School and Preparation of Education Software and its Implementation in Schools' was to:

- prepare educational materials for the subject Elements of informatics (EI) in high schools;

- provide methods for teaching and learning with computers;

- produce sample packages of educational software. 
Twenty seven teams from universities, technical universities (polytechnics), schools for teachers, and independent institutions took part in Project RRI.16. The most important results obtained in this Project were: the first textbook for informatics in Poland (see Section 6.2) and several systems and packages of educational software (see Section 6.3). All these products were made available for students and for schools - they were either bought by MEN and then sent to schools (software) or they were made available for purchase (textbooks).

\section{Project RRI.14}

The goal of Project RRI.14: 'Informatics and Computer support of Education and Research in Higher Education Institutions' was to:

- equip higher education institutions with modern computers and informatics tools;

- produce sample software packages for supporting education processes;

- prepare and train academic teachers and school staff for incorporating modern computer technology with their teaching and research.

Project RRI.14 was coordinated by Wrocław Polytechnic - coordinator Professor Wacław Kasprzak. Almost all higher education institutions in Poland participated in this Project, mainly as recipients of some modern computer labs to be used for introductory informatics courses. A curriculum for these courses was proposed by a team from the University of Wrocław, supervised by the author. Hundreds of software systems and packages were designed and produced by the participating schools then made available for all other schools participated in the Project, see the catalogue [Katalog_1].

It is worth to mention that one of the software packages designed by another team supervised by the author was later produced in 1300 copies and sent to high schools as supporting software for learning and teaching elements of informatics (see Section 6.3 for more details).

Today one should acknowledge that the two Projects from the second half of the 1980s laid a solid ground for the future decisions and activities in the area of informatics education in all types of schools on all levels of education. Schools had got modern computer systems equipped with application and educational software to support education and research (in universities). The software was listed in a uniform way in three volumes, two produced in Project RRI.14 [Katalog_1 ] and one in Project RRI.16 [Katalog_2]. Although the production and distribution of the Projects' results (books and software) were not the Projects' responsibilities, the participating institutions could freely copy and use the results for non-commercial purpose in education and research.

\section{$5 \quad$ A School Computer - Elwro 800 Junior}

In the mid-1980s Polish customers were able to buy 8-bit microcomputers abroad and bring them to Poland officially (there was no COCOM restriction on 8-bit microcomputers), they could also purchase imported microcomputers at computer 
bazaars (with local currency) or in Pewex or Baltona retail stores. Schools and universities were buying microcomputers in some quantities to form their first computer labs and to offer students the first regular classes on informatics or on using them in other subjects. Quickly, ZX Spectrum became the most popular 8-bit microcomputer in Poland. Taking this into account, MEN organised a competition for a Polish school microcomputer - the winning computer was to satisfy the following conditions:

- to work in one of its mode as ZX Spectrum, so that rich software for ZX Spectrum available in Poland could be used;

- to work under control of a disc operating system, so that the software working under $\mathrm{CP} / \mathrm{M}$ could be used;

- to communicate with a user in Polish when editing texts or programming in Logo.

Four constructions competed and the competition jury, launched by OFEK, on the basis of the findings and the results of the surveys selected microcomputer Elwro 800 Junior (called Junior hereafter) as the winner, see Figure 1. It was designed by a team from the Institute of Automation, Poznań Polytechnic, supervised by Wojciech Cellary and Paweł Krysztofiak [Cellary, Krysztofiak, 1988].

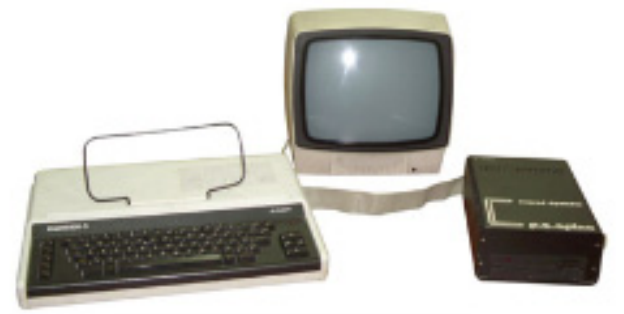

Fig. 1. Elwro 800 Junior: microcomputer, screen, tape recorder

The most important feature of Junior, in particular for schools, was its operating system $\mathrm{CP} / \mathrm{J}$ compatible with $\mathrm{CP} / \mathrm{M}$ and moreover it could control the local network Junet consisting of up to 15 microcomputers Junior. ZX Spectrum could be also connected to the Junet network. A class configuration of Juniors consisted of a local network of students' Juniors with no disc drives, a teacher's Junior with an external disc drive which was a server of files and printers, and a printer. It was very economic and effective design - all students had access to discs and to printers.

Microcomputer Elwro 800 Junior was produced in 4 versions: version 1 - a student's Junior with no disc drive, version 2 - a teacher's Junior with an external disc drive, version 3 - with an external disc drive, available for private users, and version 4 - a Junior equipped with an internal disc drive.

\subsection{Software for Juniors}

A microcomputer Elwro 800 Junior, operated under the OS CP/J, was equipped with basic software tools to control a disc drive, a magnetic tape memory, a local computer 
network Junet, and a graphic printer. The Basic interpreter and the program for magnetic tape control were compatible with those in ZX Spectrum, hence the programs for ZX Spectrum could be run on Junior. Moreover, the extended Basic interpreter for Junior controlled external devices, communication in the network, and could be used to save files on discs read from the magnetic tape memory. One could also use application software, such as: text editors ED/J (designed in Elwro) and WordStar and the database system dBase under the control of $\mathrm{CP} / \mathrm{J}$, and also spreadsheet SuperCalc in the ZX Spectrum mode.

The team which designed Junior produced also an interpreter for Logo and an environment for programming in this language [AC-LOGO]. MEN bought the rights to this software and disseminated it among school in Poland which had got Juniors. Moreover, Sinclair Logo and Polish Logo, implemented by a team supervised by S. Waligórski, and also other programming languages, such as $\mathrm{C}$, Prolog and Pascal (Borland Turbo Pascal) could be also used on Junior.

After several years of presence of Juniors in education institutions (schools and universities), software companies and in private hands, a large number of computer programs and written materials were available. A largest collection of educational software was presented during the conference 'Informatics in Schools, IV' in Błażejewko (17-20 September 1990). There were presented: 51 programs for Junior, 32 - for the IBM PC, and 7 - for both computers. The programs were designed to support a variety of school subjects: technique -5 programs, chemistry -16 , physics -30 , geodesy -2 , geography -3 , history -1 , informatics -26 , mathematics 7 , English -1 , natural environment protection -2 , pedagogy -1 , and statistics -3 . Software designed for Juniors, due to its compatibility with ZX Spectrum, ran also on other 8-bit microcomputers used in schools and at homes.

We would like to comment here on some software packages presented in Błażejewko which made Junior a real school computer:

- A package of 11 programs to support experiments in chemistry, designed by a team from Adam Mickiewicz University in Poznań;

- Authoring tool JU-LEK, designed and implemented by Witold Rudolf in his master thesis, supervised by Ewa Gurbiel (Institute of Computer Science, University of Wrocław, 1989). JU-LEK was used to prepare and execute lessons of presentation type (PT CAI - Presentation Type Computer Assisted Instruction) - lessons in JU-LEK reminded of today presentations prepared in PowerPoint. It was used to prepare lessons in various subjects - see a frame on physics in Figure 2.

Lessons made in JU-LEK consisted of at most 99 frames (or screens) connected (ordered) according to a lesson plan (graph). Each frame could contain at most 150 objects such as: texts (of at most 62 characters), graphics (a piecewise linear curve with at most 10 vertices, circle, disc, rectangle, vector), commands (delete, break, repeat, pointer, answer, run an external program in Turbo Pascal). Graphical objects could have attributes: type of a line, colour, intensity of a colour.

JU-LEK consisted of two sets of modules - for an author (a teacher) and for a student. The author's set contained two main modules, GEN - for building a 
lesson, EXE - for executing (trying) a lesson created by GEN. The purpose of the student's set was to execute a lesson built in JU-LEK. JU-LEK was implemented in Turbo Pascal 3.02A and additionally a graphics library GSJ 0.0 was used (author: K. Pielesiak, Poznań Polytechnic). JU-LEK and its author were awarded the III Prize in the 1990 National Competition for Master Degree Thesis in Informatics. The system was purchased by OFEK Jelenia Góra, which published its guide book and then disseminated to schools equipped with Juniors.

- 'Elements of Informatics' - a package of systems on various topics in informatics and in its applications, designed by a team of almost 50 authors and programmers, supervised by the author [Sysło, 1993]. The package was created in Project RRI.14 then MEN ordered 1300 its copies and sent to high schools in Poland (for more details about these programs see Section 6.3).

- a package of application software offered by VULCAN, see Section 6.6. The package consisted of: a file management system (VCOMMANDER), a text editor (VEDIT), a graphics editor (VGRAPH), spreadsheet (VCALC), database (VBASE), and a program for data visualisation (VCHART).

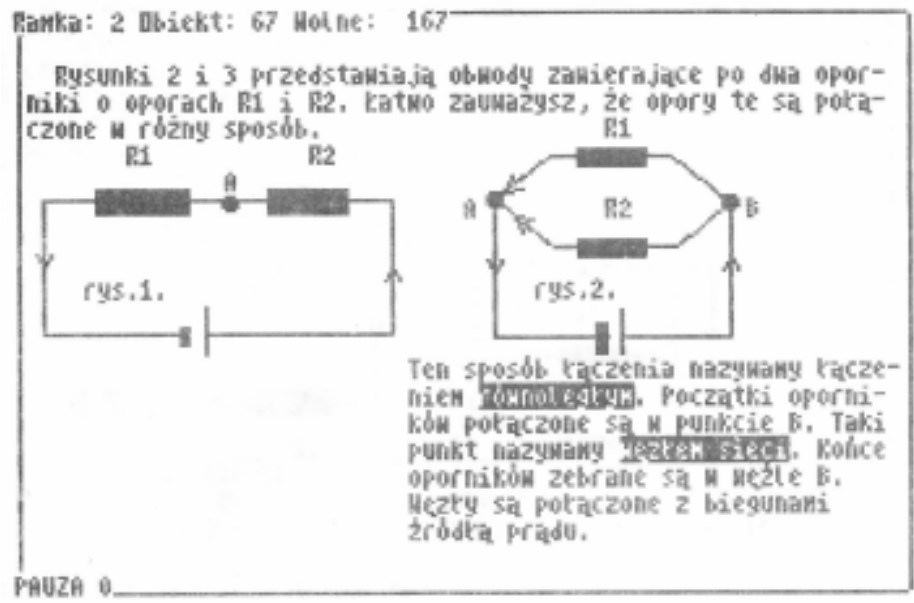

Fig. 2. A sample frame from the authoring system JU-LEK

The Software for Junior (SO CP/J, Logo, Turbo Pascal) comprised the basic computer environment for informatics lessons conducted according to the first textbook in Polish Elements of Informatics written by a team from the Institute of Computer Science University of Wrocław, supervised by the author.

\subsection{Elwro 800 Junior: Epilogue}

Elwro 800 Junior was produced by Elwro Computer Company (ZE Elwro) in Wrocław, which specialised in producing mainframe computers. Elwro was founded in February 1959 and in the beginning produced computers designed in Poland, then 
switched to a series of computers based on ICT/ICL license, and in the 1970s produced computers of the unified system based on IBM Series 360 in cooperation with other countries in the Eastern Block.

Production of Juniors was a big challenge for ZE Elwro. The company had no experience in production of personal computers in large quantities and, on the other hand, there was no supply of good quality elements for microcomputers in Poland. In fact, some elements for Juniors were imported from East Germany (processor), Soviet Union (memory), Bulgaria (disc drives), and from other countries (integrated circuits). The elements were rather of low quality and this effected the quality of the final products, microcomputers Junior.

As a producer of mainframe computers, ZE Elwro did not have a qualified service to deliver and to install personal microcomputers Junior to schools and to provide maintenance and repair service in schools. Moreover in schools, teachers were not prepared to manage with new equipment, how to: install new software, set and maintain a local network for different groups of students, or react in the case of small breakdowns, failures or malfunctions of Juniors.

In the beginning of the 1990s, with all these problems faced by the producer and the users of Juniors when the era of 8-bit microcomputers was coming to its end, MEN decided not to buy Juniors anymore and stop sending them to schools. Almost 10,000 Juniors were installed in almost 1,000 schools. In 1993, due to MEN's report, $60 \%$ of computers in schools were still 8-bit computers and more than half of them were Juniors. (Meritum, also Polish made, was another microcomputer popular in schools.

When the IBM PC begun to replace Juniors in schools, ZE Elwro designed a special drive JunServ to use IBM PC as a file and printer server for the network of Juniors. Moreover, VULCAN designed an emulator of Junior on IBM PC.

In conclusion we admit that in the second half of the 1980s, introducing microcomputers Elwro 800 Junior to schools created opportunity for thousands of students to make the first steps in learning how computers work and how to use them in a number of intellectual activities. The lesson learnt was a big step towards the future in the environment of new and rapidly changing technology. On the other hand, a number of government, public, and private initiatives made their first investments in the movement which in the years to come would cover all levels of education and far beyond any formal and non-formal education system, especially when the Internet entered the stage.

\section{The Mid-1980s - Curricula, Textbooks, Educational Software, Conference and Journals}

In this Section we shortly review the situation in educational use of computers in the second half of the 1980s, when 8-bit microcomputers dominated, just before the Internet era. Today one can observe that the activities and their results in many areas related to computers in education obtained in the late 1980s laid down a solid ground under their successful continuation in the 1990s. We focus on curricula, textbooks, 
educational software, annual conferences for teachers, and magazines and journals. Finally, educational activities of three entrepreneurs are shortly described.

\subsection{Curricula}

First curricula for teaching informatics in schools were designed in the 1960s and 1970s, for local initiatives in schools in Wrocław and in Warsaw (see Section 2). Then in the mid-1970s, another curriculum was proposed for teachers who attended in-service training in IKN and were to return to their schools to teach informatics (see Sections 2 and 3 ).

The first curriculum for the subject called Elements of informatics (EI), addressed to all high schools, was proposed by a team of PTI supervised by S. Waligórski and then approved by MEN in 1985. The curriculum was designed for 75 lessons (each 45 min. long) and covered the following topics (numbers in parenthesis denote the number of lessons) [Program_1]:

1. The Use of a microcomputer (2) - first steps in using a computer and its software.

2. Practical applications of a microcomputer (6) - learning how to use various computer applications for text editing, creating graphics and sounds, building tables and simple databases, making simulations.

3. Drawing pictures on the screen (4) - individual creation on the screen of simple elements of drawings, such as: points, lines, curves, and use them to obtain a more complex drawings; use of colors and background.

4. Procedures (12) - elements of programming using procedures, Logo environment, recursion.

5. Elements of programming style (12) - elements of structural programming, procedures and structural relations between them; top-down programming.

6. Non-elementary methods in creating graphics (12) - the use of graphics procedures with parameters.

7. Operations on texts (12) - operations on texts as lists of characters (in Logo).

8. Individual problem solving (15) - the use of acquired knowledge and skills in solving more advanced problems.

In 1990, MEN also approved another curriculum for EI in elementary schools (in fact, for the last year in elementary schools). The curriculum was designed for 60 lessons (each $45 \mathrm{~min}$. long) and covered the following topics (numbers in parenthesis denote the number of lessons) [Program_2]:

1. The use of a microcomputer (6) - preparation for using a computer and its software.

2. Practical applications of informatics (12-36) - learning in action various computer applications for text editing, creating graphics and sounds, building tables in a spreadsheet, creating a simple database of information.

3. A student as a teacher of a computer - first steps in programming (12-6) elements of programming, mainly to draw pictures (in a Logo environment). 
4. Programming more complex actions - elements of programming style (24-6) - elements of structural programming: writing procedures and planning cooperation between them.

5. Recreation with computers (6) - educational computer games.

In both curricula there was a restriction that informatics classes can be organised only in those schools which had got a computer lab for running such classes. In 2013, MEN has introduced the regulation that during informatics lessons each student should have a computer for her/his personal use (1:1 strategy).

In the mid-1990s there were three EI curricula for schools which were approved by the Ministry of Education in 1994-1995. Two of them were designed mainly for those schools in which EI classes were run for one or at most two years. One of these two curricula is focused on problem solving and algorithmics and the other - on the use of application software. The third curriculum which was proposed by the team from the Institute of Computer Science, University of Wrocław, supervised by the author, had a very general structure and consists of a number of modules which can be used to design a plan for teaching EI from one to four years with the emphasis on different aspects of informatics, e.g. problem solving, algorithmics, application software.

It is worth mentioning that Informatics (in the beginning, as Elements of Informatics) has, in Poland, been a part of the national curriculum since 1985.

\subsection{The First Textbook}

The first textbook for Elements of Informatics (under such title) was written by a team supervised by the author [Textbook_1]. It was one of the products of Project RRI.16 (see Section 4.2). It appeared in 1988 (first edition) and then, it is perhaps interesting to mention that, this textbook had a new, unchanged edition (printing) every year (two in 1995) till 1990 and more than 100,000 copies have been sold out. It is unusual for a book on informatics to remain unchanged on the market for so long. It was mainly due to the approach adopted in the book - computers and software tools were not described in full details but only with respect to the main theme (problem) of the presentation and discussion. The content of the textbook was universal although there were some key components of the contemporary informatics and technology missed, especially related to computer networks and computer supported communication, which entered schools later in the 1990s. The content of the book was (and still is) universal and we are not surprised today to see our book in hands of students and teachers:

1. What is informatics. Elements of history of computers and informatics.

2. How computers are designed and how they work (operating systems).

3. Playing and learning (turtle graphics - Logo).

4. From problems to programs (elements of programming in Turbo Pascal).

5. Designing one's own directory (database in Turbo Pascal).

6. Calculations in mathematics (elements of numerical methods).

7. Computing faster - efficiency of algorithms (elements of algorithmics and algorithms complexity).

8. Writing with no paper and pencil - text editing.

9. Easy and effective managing of a small business (spreadsheet). 
The textbook was accompanied by a book with some solutions of all problems from the textbook [Texbook_2] and by a guide book for teachers [Texbook_3] which was the first text in Polish on the methodology of using computers in schools - it can be considered as a textbook on the didactics of informatics. Package EI (see Section 6.3) was used in all three volumes as supporting software for students and teachers.

\subsection{Educational Software}

In Section 5.1 we have described in details educational software designed and produced for Juniors. These software packages were sent (from ZE Elwro or from $\mathrm{MEN}$ ) to schools equipped with Juniors and then were available for all Junior users in schools.

\subsubsection{Educational Software for Chemistry}

A team from Adam Mickiewicz University in Poznań, supervised by Andrzej Burewicz and Hanna Gulińska, designed a package of 11 programs for Juniors to support experiments in chemistry (see Section 5.1). This team has been (and remains today) very active in providing students and schools with tools for computer assisted learning and instruction in chemistry [Burewicz at al.].

\subsubsection{Educational Software for Elements of Informatics}

A software package - EI (Elements of Informatics) - was designed for IBM PC by a team supervised by the author in Project RRI.14 (see Section 4.2) to support teachers of informatics and of related subjects [Sysło, 1993]. The software was comprehensively tested and accompanied by its documentation and educational materials (more than 1,000 pages). Then Foundation OFEK produced 1,300 of its copies and delivered them to high schools.

Package EI consisted of 10 educational systems:

1. SB - a system for constructing and executing flow-charts of algorithms.

2. DYSKIETKA - a system for presenting basic operations on a computer file system and demonstrating their effects.

3. TP-TOOL - a set of tools for supporting learning of programming in Turbo Pascal.

4. ESO - a system for demonstrating operating system commands and learning elements of concurrent programming.

5. DISC-MATH - a system consisting of 6 programs for supporting learning algorithms and data structures: operations on list and tree data structures, sorting algorithms, operations and algorithms on graphs, backtracking algorithms, a model of a universal computer.

6. EKO-SYM - a system for simulation of eco-processes.

7. MAT-STAT - a system for supporting lessons on probability and statistics and also for estimating parameters based on experimental data. 
8. PS-STAT - a system for analysing experimental data addressed to nonspecialists in other areas.

9. ASD - a system for demonstrating and analysing algorithms and data structures.

10. MET-NUM - a system for supporting learning numerical methods (computer realisation of mathematical calculations) and for performing some numerical calculations.

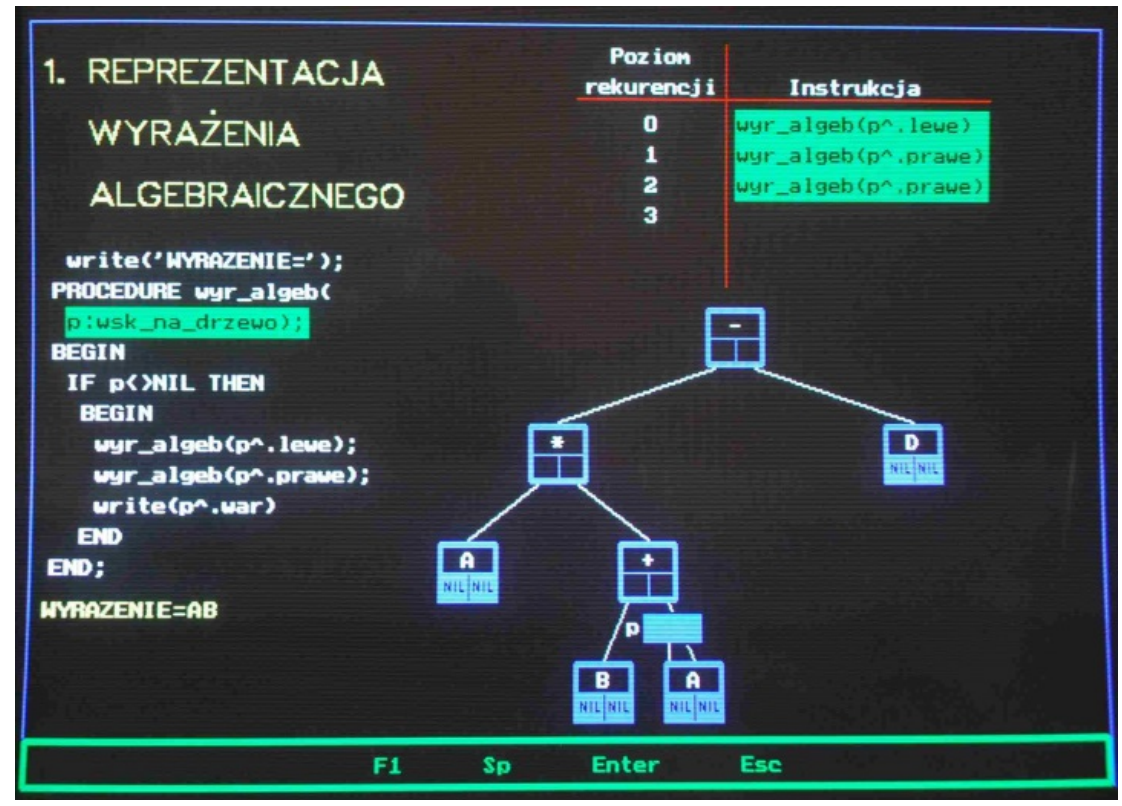

Fig. 3. A screen with Package EI - demonstration of a tree data structure

The package was used to support learning and teaching of informatics (systems: SB, DYSKIETKA, TP-TOOL, ESO, DISC-MATH, ASD, EKO-SYM, MAT-STAT, PS-STAT, MET-NUM), mathematics (systems: DISC-MATH and ASD, MATSTAT, MET-NUM), statistics (systems: EKO-SYM, PS-STAT, MAT-STAT), and biology (system EKO-SYM).

Package EI, supported by very rich written educational materials, could be used in a number of ways: by a teacher, during a lecture or exercises - to illustrate concepts and their properties, and to demonstrate methods and algorithms; by students - during a teacher's demonstration, when working in groups and individually. Depending on the preparation and expertise level of students, package EI could be gradually used:

- as a tool for demonstrating concepts, their properties, methods and algorithms;

- as a demonstration tool in which the user can make experiments with different values of parameters of her/his own choice;

- to plan and design exercises supported by the package;

- to write their own programs utilising some software modules available in the package. 
In our vision, when we were designing and implementing Package EI, similarly to Seymour Papert [1980]: the student programs the computer instead of the computer is being used to program the student.

From today's point of view, package EI appeared ahead of time - teachers were not prepared and trained to use it. Some of the systems from EI have been redesigned and implemented for the Windows environment, and now are available as open educational resources, see http://mmsyslo.pl/ Materialy/Oprogramowanie.

\subsubsection{Educational Software for Mathematics}

As indicated many times in this paper, mathematicians were very active in introducing computers to classrooms to support instruction. Several packages of software for mathematics were designed and produced for Junior (see Section 5.1), e.g., by VULCAN. Some packages for mathematics were also designed in Projects RRI.14 and RRI.16, e.g. a package Kartezjusz. Package EI described above, contained some systems for augmenting and supporting mathematical topics, mainly from an informatics point of view, e.g., for numerical calculations.

Very active was a group of mathematicians from a seminar of Wacław Zawadowski at Warsaw University - A. Walat, M. Dąbrowski, K. Dałek, E. SepkoGuzicka, W. Guzicki, W. Jędrychowski and others - who designed and produced many software packages (for Junior and Windows environments) for mathematics education, in particular in the form of textbook extensions (see [Walat, Zawadowski, 1988]) - computer programs were used to better explain and visualise mathematical concepts and to perform some sample calculations to demonstrate behaviour of mathematical formulas and problem solutions.

\subsection{Conference 'Informatics in Schools'}

In 1985, MEN and two local computer institutions in Wałbrzych (ZETO Świdnica and NOT Wałbrzych) initiated an annual conference 'Informatics in Schools' which has been organised for the next 20 years (the author was the program chairman of the last 15 conferences). Now these annual meetings are continued as 'Informatics in Education'.

The conference was organised in cooperation with local higher education institutions in different cities of Poland and gathered each year 400-600 participants coming from schools and universities, software and hardware companies and also decision makers from the institutions which ran schools. The conference was an opportunity to exchange ideas, solutions, and school experience. School and academic teachers had a chance to present research and practice papers, and companies arranged exhibitions of new software and hardware products. It was the main place in Poland where the school (education practice) was meeting the market (companies) proposals. 


\subsection{Magazines and Journals}

The most influential computer magazine in Poland in the second half of the1980s was Bajtek. It was established in 1985; Władylsaw Majewski was his first editor in chief. Bajtek was popular among the Polish youth and played an important role in disseminating computer knowledge. ... Its goal was described as follows: Bajtek is a popular magazine dedicated to all issues linked with information processing. [Wasiak, 2014]. The second Polish magazine, Komputer, established in 1986, addressed readers interested in using computers in their professional careers.

In 1990, a monthly journal Komputer w Szkole (eng. Computer in School) was funded by OFEK, fully dedicated to the use of computers in formal and in-formal education. The journal published: curricula and syllabuses, official documents and reports from MEN, reports on school initiatives and experiences, research papers by school and academic teachers, conference reports, and translations of articles written by international experts (e.g., by A.P Ershov, Eric de Corte). The journal was a very important source of information and materials for school teachers.

Computer magazines and journals were very popular among members of computer clubs which provided young people access to computers and programming courses. Such clubs were established under the auspices of local and central youth associations, companies, and schools. In 1993, at a total of 3,792 state-sponsored cultural centres, 842 had computer clubs and 422 with computer rooms. The clubs totaled 15,283 members, including 11,499 children under 15 (see [Wasiak, 2014]). In many cases computer clubs were children's first contact with computers.

\subsection{Institutions Supporting Computers in Education}

As indicated above, in the 1980s, before the democratic break-down in Poland in1989, several associations, private or non-public institutions, and companies were funded in Poland, which were involved in computerisation of schools by: sharing their knowledge and experience with MEN and with schools (PTI), providing schools with software and hardware solutions, training teachers and decision makers. Below, we shortly describe the role and achievements of three such institutions.

\subsubsection{PTI - Polskie Towarzystwo Informatyczne}

The Polish Information Processing Society (PTI) was established in May 1981 in Warsaw. One of its goals was (and still is) to support education (informatics education and computer use in other disciplines) on all levels and in all types of schools. PTI was very active in education when the first personal microcomputers arrived in Poland, in particular - in schools. The Society donated microcomputers to teachers' training courses, and funded and established computer clubs in public places and in schools. Very active was the Society's Branch in Wrocław led by Zygmunt Mazur, which initiated a movement 'Komputer w tornistrze' (eng. Computer in a School Backpack) and in 1985 organised 'Wakacje z komputerem' (eng. Vacations with a computer). 
As mentioned above, the PTI team led by S. Waligórski, in 1985 proposed a curriculum for the subject Elements of informatics, which then was approved by MEN for the use in schools. PTI was also very active in the process of choosing Elwro 800 Junior as a Polish school computer.

\subsubsection{VULCAN}

The VULCAN company, founded in Wrocław in 1988, was involved in designing and producing software for education and for school administration. First programs ran on ZX Spectrum and Elwro 800 Junior, and then the company switched to Windows software. In 1989 VULCAN sold to MEN 40 education programs for ZX Spectrum and Elwro 800 Junior (see Section 5.1) and invested the profit into its development.

In the second half of the 1980s, Vulcan participated in the government Project RRI-16 (see Section 4.2), as a software designer and producer. In the beginning of the 1990s, VULCAN represented Poland in the Program EPES (European Pool of Educational Software), and its duty was to adopt foreign programs to the requirements of Polish schools. (System DISC-MATH from Package EI, see Section 6.3, represented Poland in the Pool).

\subsubsection{OFEK - Ogólnopolska Fundacja Edukacji Komputerowej}

National Foundation for Computer Education was founded in Wrocław in 1986, as an initiative of Wrocław companies and academic institutions. The Foundation specialises in teacher training and in delivery of computer equipment to schools. It operates through branches. In the 1990s, the OFEK branch in Jelenia Góra was responsible for publications - it published the second edition of the first textbook for informatics in Poland (see Section 6.2) and it was a publisher of the journal Komputer w Szkole.

The most active branch of OFEK is now in Poznań. It was involved in editing, publishing and delivering to high school the Package EI (see Section 6.3). Now this branch of OFEK is mainly involved in teacher training - in the project Intel - Teach to the Future almost 80000 teachers were trained.

\section{$7 \quad$ The Years That Have Followed}

In the 1990s, the history of computers in schools and in education was greatly influenced by a new communication medium - the Internet. IBM PC standard (in hardware and in system and application software) dominated the school equipment, which recently is moving towards mobile solutions. Now our students are always connected to the world by devices they carry in their pockets. Recently a new challenge has emerged - can they learn while they are connected?

In the mid-1990s in Poland, the term 'information and communication technology - ICT' was accepted by the education policy makers and a new subject Information Technology was introduced to the curriculum by the Education Reform of 1997 and then to high schools in 2002. Informatics as a separate subject for all students returned to high schools in 2012 as a result of the next reform of 2008, for more details see [Sysło, Kwiatkowska, 2008; Sysło, 2011]. 
Acknowledgements. The author wishes to thank many colleagues who provided him with many historical materials and memories. Special thanks go to: A. Skowron, A. Walat, J. Nowak, W. Rudolf, W. Cellary, P. Krysztofiak, G. Hardt-Olejniczak, Z. Rogowski, and K. Święcicki.

\section{References}

AC-LOGO: Podręcznik użytkownika AC-LOGO. Wersja 1.2 dla IBM PC, OFEK, Jelenia Góra (1993)

Bielecki, J.: Turbo Pascal. Oprogramowanie Elwro 800 Junior. WN-T, Warszawa (1988)

Burewicz, A., Gulińska, H., Miranowicz, N., Szmidt, H.: Edukacyjne programy komputerowe w nauczaniu chemii. OFEK Jelenia Góra 1992. Biblioteka metodyczna 'Komputera w Szkole' (5) (1992) Burewicz, A. (red.)

Cellary, W., Rykowski, J.: System Operacyjny CP/J dla mikrokomputera Elwro 800 Junior. WN-T, Warszawa (1988)

Cellary, W., Krysztofiak, P.: Elwro 800 Junior. WN-T, Warszawa (1988)

CP/J, Basic - Opis języka, Oprogramowanie Elwro 800 Junior, Wrocław (1987)

Czyżo, E., Zawadowski, W.: Pierwsze kontakty z mikrokomputerem ZX Spectrum. WSiP, Warszawa (1987)

Gurbiel, E., Krupicka, H., Płoski, Z.: Programowanie i Logo. Wydawnictwo Uniwersytetu Wrocławskiego, Wrocław (1987) Płoski, Z. (red.)

Hallay, J.: Algorytmy. In: Matematyka, Część 2. Informatyka, Zeszyty Naukowe IKN, pp. 6-46. WSiP, Warszawa (1981)

Iglewski, M., Madey, J., Matwin, S.: Pascal. Język wzorcowy. Pascal 6000. WN-T, Warszawa (1979)

Kania, J.: Pierwsze kroki w Logo. WSiP, Warszawa (1987)

Katalog_1: Katalog oprogramowania użytkowego opracowanego przez szkoły wyższe w ramach programu RRI.14 (1988-1990), Część I i II. Wydawnictwo Politechniki Wrocławskiej, Wrocław (1990)

Katalog_2: Katalog oprogramowania dydaktycznego, M.M. Sysło (red.), Materiały Konferencji 'Informatyka w szkole, VI', Błażejewko, Wrzesień 1990, IIUWr-MEN-OFEK (1990)

Łukaszewicz, J.: Programowanie dla maszyny Elliott 803. PWN, Warszawa (1966)

Papert, S.: Mindstorms. Children, Computers, and Powerful Ideas. Basic Book, New York (1980)

Paszkowski, S.: Algol 60, Wydanie I. PWN, Warszawa (1965)

Pawlak Z., Skowron A., Elementy teorii maszyn matematycznych dla IV klasy, Skrypt dla uniwersyteckich klas matematycznych w XIV Liceum Ogólnokształcącym im. K. Gottwalda w Warszawie, Instytut Pedagogiki, Warszawa (1970)

Pawlak, Z.: Maszyny matematyczne. PZWS, Warszawa (1971)

Program_1: Program Liceum Ogólnokształcącego. Elementy informatyki, MOiW, WSiP, Warszawa (1985)

Program_2: Program Szkoły Podstawowej. Elementy informatyki, Klasa VIII, MOiW, WSiP, Warszawa (1990)

Rudolf, W.: JU-LEK wersja 1. System autorski dla mikrokomputera Elwro 800 Junior, OFEK, Jelenia Góra (1990)

Rudolf, W.: System autorski JU-LEK. Informatyka 8, 18-21 (1990)

Sepko-Guzicka, E., Guzicki, W.: Zastosowanie komputerów w nauczaniu matematyki. IKN, Warszawa (1987) 
Skowron, A.: Zbiór zadań z teorii maszyn matematycznych dla uniwersyteckich klas matematycznych w XIV Liceum Ogólnokształcącym im. Gottwalda w Warszawie, Instytut Pedagogiczny, Warszawa (1970)

Skowron, A.: Podstawy teorii maszyn matematycznych, Materiały pomocnicze dla nauczycieli. Tom 6. IKN, Warszawa (1974)

Skowron, A.: Konspekty lekcyjne eksperymentalnego nauczania informatyki w III klasach szkół średnich, Część V. Algorytm Uniwersalny, IKN, Warszawa (1976)

Sysło, M.M.: Pakiet 'Elementy Informatyki'. Komputer w Edukacji 1, 15-25 (1994)

Sysło, M.M.: From elements of informatics to information technology across curriculum: the Polish approach. Int. J. Cont. Engineering and Lifelong Learning 11, 526-533 (2001)

Sysło, M.M., Kwiatkowska, A.B.: The challenging face of informatics education in Poland. In: Mittermeir, R.T., Sysło, M.M. (eds.) ISSEP 2008. LNCS, vol. 5090, pp. 1-18. Springer, Heidelberg (2008)

Sysło, M.M.: Outreach to prospective informatics students. In: Kalaš, I., Mittermeir, R.T. (eds.) ISSEP 2011. LNCS, vol. 7013, pp. 56-70. Springer, Heidelberg (2011)

Textbook_1: Dańko W., Gurbiel E., Jarzębowski Z., Kołczyk E., Krupicka H., Łukojć K., Płoski Z., Sysło M.M., Witkowski J., Zuber R.: Elementy informatyki, M.M. Sysło (red.). Wydawnictwo Uniwersytetu Wrocławskiego, Wrocław (1989); WN PWN, Warszawa (1991)

Textbook_2: Gurbiel E., Jarzębowski Z., Kołczyk E., Krupicka H., Łukojć K., Płoski Z., Sysło M.M., Zuber R.: Elementy informatyki. Rozwiązania zadań, M.M. Sysło (red.). OFEK Jelenia Góra (1990); Biblioteka metodyczna 'Komputera w Szkole' (4). WN PWN, Warszawa (1995)

Textbook_3: Gurbiel E., Hardt-Olejniczak G., Kołczyk E., Krupicka H., Łukojć K., Płoski Z., Sysło M.M., Witkowski J., Zuber R.: Elementy informatyki. Poradnik metodyczny dla nauczycieli, M.M. Sysło (red.). WN PWN, Warszawa (1997)

UNESCO: Information and Communication Technology in Education. A curriculum for schools and programme of teacher development, UNESCO, Paris (2002)

Walat, A.: Ćwiczenia z podstaw informatyki. Zbiór zadań z rozwiązaniami przykładowymi i uwagami metodycznymi, Część I i II. IKN, Warszawa (1978)

Walat, A., Zawadowski, W.: Instrukcja do kasety 'Matematyka 6'. WSiP, Warszawa (1988)

Walat, A., Zawadowski, W.: Matematyka III. Podręcznik dla liceum ogólnokształcącego i liceum zawodowego. WSiP (1988)

Walat, A.: Wybrane problemy dydaktyki informatyki, OFEK Jelenia Góra. Biblioteka metodyczna 'Komputera w Szkole' (6) (1990)

Waligórski, S.: Programowanie w języku Logo. Oprogramowanie Elwro 800 Junior. WN-T, Warszawa (1990)

Wasiak, P.: Playing and Copying: Social Practices of Home Computer Users in Poland During the 1980s. In: Alberts, G., Oldenziel, R. (eds.) Hacking Europe: From Computer Cultures to Demoscenes, History of Computing. Springer, London (2014)

Witek, S.: Próba kształcenia programistów w liceum ogólnokształcącym. Matematyka XIX 1, 24-30 (1966)

Zuber, R.: O realizacji przedmiotu 'Programowanie i obsługa maszyn cyfrowych'. Matematyka XIX 2, 76-83 (1966)

Zuber, R.: Metody numeryczne i programowanie. PZWS, Warszawa (1972) 